\title{
DETERMINATION OF LOCAL QUASI-GEOID IN CENTRAL ANATOLIA FOR ENGINEERING AND GIS PURPOSES
}

\author{
${ }^{1}$ Muzaffer KAHVECI, ${ }^{2}$ Ekrem TUŞAT, ${ }^{3}$ Ferruh YILDIZ, ${ }^{4}$ Fatih SARI, ${ }^{5}$ Fariz MİKAİLSOY \\ 1,2,3 Selcuk University, Engineering Faculty, Department of Geomatic Engineering, Konya, Turkey \\ ${ }^{4}$ Selcuk University, Cumra School of Applied Sciences, Cumra, Konya,Turkey \\ ${ }^{5}$ Igdir University, Faculty of Agriculture, Igdir, Turkey \\ ${ }^{1}$ mkahveci@selcuk.edu.tr, ${ }^{2}$ etusat@selcuk.edu.tr, ${ }^{3}$ fyildiz@selcuk.edu.tr, ${ }^{4}$ fatihsari@selcuk.edu.tr, \\ 5fariz.m@igdir.edu.tr
}

(Geliş/Received: 08.11.2018; Kabul/Accepted in Revised Form: 17.12.2018)

\begin{abstract}
Requirement for a high resolution geoid model has increased substantially during the last few decades especially with the advent of Global Positioning System (GPS). Many countries across the world have already developed their own geoidal model which serve as the means of deriving orthometric heights from GNSS observations. On the other hand, the need for transformation of the ellipsoidal heights derived from GNSS observations to the physical orthometric heights has forced geodesists to determine the high precision local geoid heights. Besides, because orthometric heights are used in engineering and GIS applications, local quasi-geoid determination studies have become especially important. As it is well known, Turkey is situated on a tectonically very active region and earthquakes occurring in different times cause deformations in heights of levelling points of Turkish National Vertical Network. On the other hand, National Mapping Agency of Turkey (GDM: General Directorate of Mapping) which is responsible for the establishment and maintenance of national geodetic networks compute geoid models for whole Turkey and release them for public use in different periods. These GDM-computed geoid models are called "hybrid geoid" models. Hybrid geoid models are computed with the combination of gravimetric geoid models and geoid heights on the GPS_levelling points. And it is also known that the absolute accuracies of these geoid models are nearly at the $10 \mathrm{~cm}$ level or even worse. But, the requested accuracy is about better than $5 \mathrm{~cm}$. Hence, in order to prove that the required accuracy levels can be achieved, a local gravimetric and quasi-geoid determination project using the resources of Selçuk University was initiated. Project area has been planned to cover a limited part of Central Anatolia including Konya. Necessary basic data (gravity, levelling etc.) for this project have been obtained in the field by performing observations/measurements. Some other necessary data such as absolute gravity values have been obtained from GDM. And as the next phase, high accuracy (better than $5 \mathrm{~cm}$ ) local gravimetric and quasi-geoid models will be computed for the limited part of Central Anatolia using the above mentioned data. In order to be able to reach this goal suitable geoid computations softwares must be used. In this project, we will use DFHRS developed by the Karlsruhe Applied Sciences and GRAVSOFT softwares. According to the results to be obtained from this project, a more comprehensive project will be launched and the project area will be expanded. Thus, additional gravity, levelling and GNSS measurements will be carried out in the new project area for the determination of a high accuracy regional gravimetric geoid.
\end{abstract}

Key Words: Ellipsoidal height, GIS, GNSS, Gravimetric geoid, Orthometric height, Quasi geoid

\section{İç Anadolu Bölgesinde Mühendislik ve CBS Amaçlı Quasi-Geoid Belirlenmesi}

ÖZ: Yüksek çözünürlüklü bir jeoit model için gereklilik, özellikle Küresel Konumlandırma Sisteminin (GPS) gelişi ile son birkaç on yılda önemli ölçüde artmıştır. Dünyadaki pek çok ülke, GNSS 
gözlemlerinden ortometrik yükseklik elde etme aracı olarak hizmet eden kendi jeoidal modellerini zaten geliştirmiştir. Öte yandan, GNSS gözlemlerinden elde edilen elipsoidal yüksekliklerin fiziksel ortometrik yüksekliklere dönüştürülmesi ihtiyacı, jeodezicileri yüksek hassasiyetli yerel jeoit yüksekliklerini belirlemeye zorlamıştır. Ayrıca, mühendislik ve CBS uygulamalarında ortometrik yükseklikler kullanıldığından, yerel yarı-jeoit belirleme çalışmaları özellikle önem kazanmıştır. İyi bilindiği gibi, Türkiye tektonik olarak çok aktif bir bölgede yer almakta ve farklı zamanlarda meydana gelen depremler, Türk Ulusal Dikey Ağının tesviye noktalarının yüksekliklerinde deformasyonlara neden olmaktadır. Öte yandan, ulusal jeodezik ağların kurulması ve sürdürülmesinden sorumlu olan Ulusal Haritacılık Ajansı (HGM: Harita Genel Müdürlüğü) tüm Türkiye için jeoit modelleri hesaplamakta ve bunları farklı dönemlerde kamuya açık hale getirmektedir. Bu HGM-bilgisayarlı jeoit modellere "hibrit jeoit" modelleri denir. Hibrit jeoit modeller, GPS_levelling noktalarındaki gravimetrik jeoit modellerin ve jeodezik yüksekliklerin kombinasyonu ile hesaplanmıştır. Ayrıca, bu jeoit modellerin mutlak doğruluklarının neredeyse $10 \mathrm{~cm}$ seviyesinde veya daha da kötü olduğu bilinmektedir. Ancak, istenen doğruluk $5 \mathrm{~cm}$ 'den daha iyidir. Bu nedenle, istenen doğruluk düzeylerinin elde edilebileceğini kanıtlamak için, Selçuk Üniversitesi'nin kaynaklarını kullanan yerel bir gravimetrik ve yarı-jeoit belirleme projesi başlatılmıştır. Proje alanı Konya dahil olmak üzere Orta Anadolu'nun sınırlı bir bölümünü kapsayacak şekilde planlanmıştır. Bu proje için gerekli temel veriler (yerçekimi, tesviye vb.) Gözlem / ölçümler yapılarak sahada elde edilmiştir. HGM'den mutlak yer çekimi değerleri gibi diğer gerekli veriler elde edilmiştir. Ve bir sonraki aşama olarak, yukarıda belirtilen veriler kullanılarak Orta Anadolu'nun sınırlı kısmı için yüksek doğruluk ( $5 \mathrm{~cm}$ 'den daha yüksek) yerel gravimetrik ve yarı-jeoit modeller hesaplanacaktır. Bu amaca ulaşabilmek için uygun jeoit hesaplamalar kullanılmalıdır. Bu projede, Karlsruhe Uygulamalı Bilimler ve GRAVSOFT yazılımları tarafından geliştirilen DFHRS'yi kullanacağız. Bu projeden elde edilecek sonuçlara göre daha kapsamlı bir proje başlatılacak ve proje alanı genişletilecektir. Böylece, yüksek hassasiyetli bölgesel gravimetrik jeoidin belirlenmesi için yeni proje alanında ek yerçekimi, tesviye ve GNSS ölçümleri gerçekleştirilecektir.

Anahtar Kelimeler: Elipsoidal Yükseklik, CBS, GNSS, Gravimetrik Jeoit, Ortometrik Yükseklik, Quasi Jeoi,

\section{INTRODUCTION}

With the advent of GPS, conventional terrestrial positioning techniques have been replaced by realtime GNSS services in practice and thus agencies now provide heights almost effortlessly to the users. Almost all countries have their own Continuously Operating Reference Stations (CORS) Networks. And many corrections are being disseminated via RTCM messages through these CORS networks. For example, in Turkey CORS-TR (TUSAGA-Aktif) is in use which provides real-time 3D coordinate corrections in ITRF96 (International Terrestrial Reference Frame-1996). In Turkey, there are also some other local CORS networks operated by local municipalities such as Istanbul, Ankara and Konya. These services can provide the end user with highly accurate real time positions at a relatively low cost. In corresponding GNSS online processing, the positioning problem is divided into two parts: horizontal positioning and vertical positioning. The horizontal position is transformed to the local coordinate systems through a datum transformation. In this way the horizontal positions can easily be integrated with other traditional horizontal positioning techniques.

But for the height component the situation is different. Heights are a necessary component of surveying and mapping applications. As it is well-known, the GNSS-derived height is the ellipsoidal height. On the other hand, in engineering projects and GIS applications orthometric height (H:sea-level heights referring to Earth gravity field) is used. In practice orthometric heights refer to Mean Sea Level (MSL) as their (vertical) datum thus called practical heights. Practical heights must be physically meaningful Thus, the GNSS-based determination of orthometric heights " $\mathrm{H}$ " requires the transformation of the GNSS-derived ellipsoidal heights to the respective geoid model (i.e. physically defined height 
reference surface). Requirement for a high resolution geoid model has increased substantially during the last few decades especially with the advent of Global Positioning System (GPS). Many countries across the world have already developed their own geoidal model which serve as the means of deriving orthometric heights from GNSS observations. On the other hand, the need for transformation of the ellipsoidal heights derived from GNSS observations to the physical orthometric heights has forced geodesists to determine the high precision local geoid heights. Consequently, GNSS positioning services such as CORS-TR serving also for navigation, mobile GIS and mobile IT applications require the establishment and maintenance of a geodetic infrastructure for GNSS positioning services.

Turkey is situated on a tectonically very active region and earthquakes cause deformations in heights of levelling points of Turkish National Vertical Network. On the other hand, National Mapping Agency of Turkey (GDM: General Directorate of Mapping) is responsible for the establishment and maintenance of national geodetic networks compute geoid models for whole Turkey and release them for public use in different periods. These GDM-computed geoid models are called "hybrid geoid" models. Hybrid geoid models are computed with the combination of gravimetric geoid models and geoid heights on the GPS_levelling points. And it is known that the absolute accuracies of these geoid models are nearly at the $10 \mathrm{~cm}$ level or even worse. But, the requested accuracy is about better than $5 \mathrm{~cm}$ for engineering works. Hence, in order to prove that the required accuracy levels can be achieved, a local gravimetric and quasi-geoid determination project using the resources of Konya Selçuk University was initiated. Project area has been planned to cover a limited part of Central Anatolia including Konya.

Necessary basic data (gravity, levelling etc.) for this project have been obtained in the field by performing GPS and gravity observations/measurements. Some other necessary data such as absolute gravity values have been obtained from GDM. And as the next phase, high accuracy (better than $5 \mathrm{~cm}$ ) local gravimetric and quasi-geoid models will be computed for the limited part of Central Anatolia using the above mentioned data. In order to be able to reach this goal suitable geoid computations softwares must be used. In this project, we will use DFHRS (The Digital Finite-element Height Reference Surface) which applies a geometric approach and developed by the Karlsruhe Applied Sciences and GRAVSOFT softwares. The principle of the DFHRS software is based on the parametric model of $\mathrm{N}(\varphi, \lambda$, h) as a continuous polynomial height reference surface (HRS). Following the quasi-geoid computation, when we reach the requested accuracy level, namely better than $5 \mathrm{~cm}$, then it will have been shown that the GNSS based determination of orthometric heights $(\mathrm{H})$ is much faster, easier to handle and much more economic, in comparison to classical geodetic levelling (DFHRS 2018). On the other hand, GRAVSOFT is a package of FORTRAN programs for gravity field modelling. Using the program empirical covariance function and its analytic modelling is determined and thus geoid determination using least-squares collocation is performed (Sanso et al., 2008).

It can generally be said that it is possible to obtain a gravimetric geoid better than $10 \mathrm{~cm}$ accuracy by using global models and gravity data with 1-2 mGal accuracy. And you can only check such geoid only with GNSS/levelling heights which provide better accuracies. Thus, according to the results to be obtained from this project, a more comprehensive project will be launched and the project area will be expanded. Thus, additional gravity, levelling and GNSS measurements will be carried out in the new project area for the determination of a high accuracy regional gravimetric geoid.

Consequently, in this paper, all works carried out within the framework of this project and the reached preliminary results will be presented. Because this projects has just initiated, here only the preliminary results obtained by DFHRS software are presented.

\section{GEOID AND THE DFHRS SOFTWARE}

As it has been stated above heights are a necessary component of surveying and mapping (including GIS) applications particularly if the projects require a 3 dimensional work. In practice, we use practical heights (H:orthometric heights) which refer to mean sea level (MSL) as our vertical datum. Practical heights are defined by means of real gravity observed at the Earth's surface. On the other hand, if we 
need a very precise vertical datum for our practical heights then MSL is no longer a vertical datum particularly for scientific studies and national datums. In this case an equipotential surface of the Earth's gravity field, the geoid, must be determined. Hence, Practical heights are defined by means of real gravity observed at the Earth's surface.

Due to the non-parallelism of equipotential surfaces levelling loops do not close (impossible to adjust) and there is no uniqueness in heights. Thus, we must use properly defined heights instead of levelled heights (Vanicek, 2009), (Figure-1).

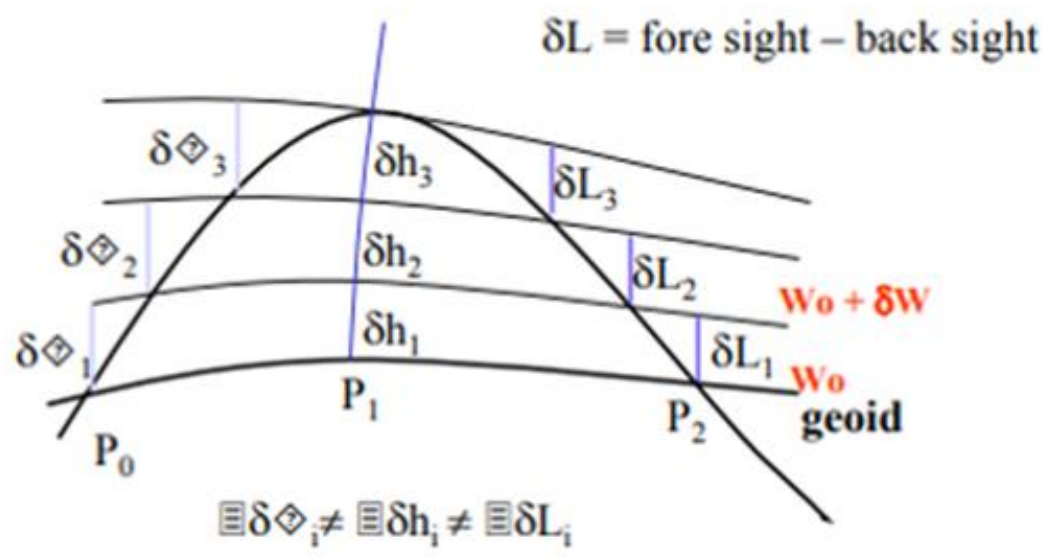

Figure 1. Geodetic levelling: Levelling is affected by the Earth Gravity Field (Vanicek, 2009)

There are three types of geoid-referenced height, namely, dynamic height, orthometric height and the normal height in geodesy. Each of these heights basically refers to the difference in gravity potential between the geoid and the point in question. This potential difference is known as the geopotential number (Jekeli, 2000). Different height systems can be related to each other by the geopotential number $(\mathrm{Cp})$. Hence, geopotential numbers create the most natural height system but they are impractical. Dynamic heights: Any point has a unique geopotential number (with respect to the defined local geoid), scaled by a reference gravity " $\%_{0}$ ", can be used as a height coordinate of the point and computed by the following equation 1.

$$
H_{p}^{d y n(j)}=\frac{c_{P}^{(j)}}{Y_{0}}
$$

Here, $\gamma_{0}=9.806199203 \mathrm{~m} / \mathrm{s}^{2}$ and called normal gravity for GRS80 ellipsoid. In above equation, $H_{p}^{d y n(j)}$ is the dynamic height of $\mathrm{P}$ (with respect to vertical datum) and has a physical meaning (i.e. water always flows downward) and thus the dynamic heights are unique. ${ }^{H_{p}^{d y n}(j)}=0$ for all points on the geoid.

Orthometric heights: The orthometric height of a point on the Earth surface is the distance $\mathrm{H}_{\mathrm{o}}$ from the point to the geoid, measured along the plumb line of $\mathrm{P}$, and given as below (Figure-2):

$$
H_{p}^{j}=\frac{c_{P}^{(j)}}{\overline{\mathrm{E}}_{p}^{j}}
$$




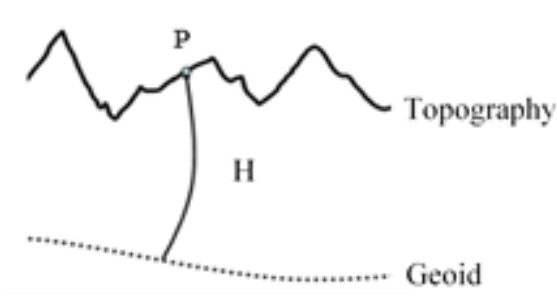

Figure 2. Orthometric height $(\mathrm{H})$

In equation $2, \overline{\mathrm{g}}_{p}^{j}$ is the mean gravity along the plumb line of $\mathrm{P}$.

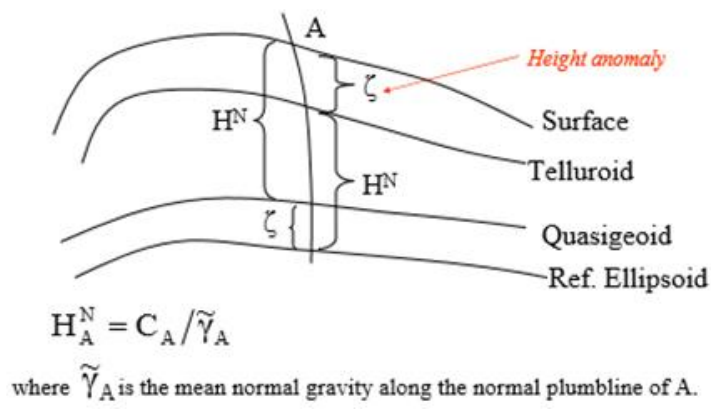

Figure 3. Normal Height and Quasi-geoid (Jekeli, 2000)

Normal height: It is possible to define a similar geometrically interpretable height that avoids a density hypothesis for the crust. This is accomplished by introducing the normal gravity field. Normal gravity field is defined as the gravity field generated by an Earth-fitting ellipsoid (Jekeli, 2000). Normal height describes height above the quasigeoid, Figure-3. Geoid and quasigeoid coincide along the mean shoreline and at sea.

\section{PROJECT PLANNING AND FIELD WORK}

Requirement for a high resolution geoid model has increased substantially during the last few decades especially after advent of Global Positioning System (GPS). Many countries across the world have already developed their own geoidal model which serve as the means of deriving orthometric heights from GNSS observations. On the other hand, the need for transformation of the ellipsoidal heights obtained from GNSS technique to the orthometric heights has forced geodesists to determine the high precision geoid heights.

Necessary basic data (absolute gravity values and heights) for this project have mainly been obtained from GDM's archive. And following the necessary investigation on topographic maps, and using the obtained data a high accuracy gravimetric geoid will have been determined for the project area in which Konya will be center. For this purpose a $140 \mathrm{~km}$-long line has been determined between Ankara and Yozgat. And along this line relative gravity, GPS and levelling measurements were performed at 21 points. Project area is seen on Figure-4. Gravity measurements were performed using Scintrex CG-5 AUTOGRAV device obtained from Dokuz Eylül University (Izmir). Absolute gravity measurements at Ankara and Yozgat points were obtained from GDM. 


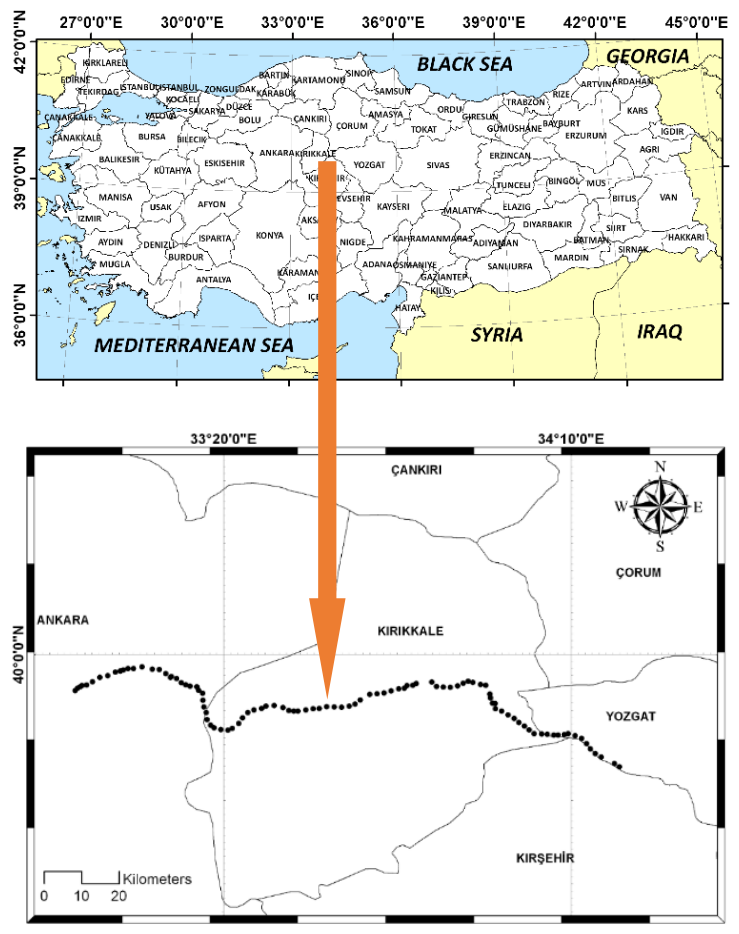

Figure 4. Project Area

Project team consists of Konya Technical University academicians and MSc/PhD students. And it is anticipated to complete the project within 24 months including the training issues.

\section{CONCLUSIONS}

Requirement for a high resolution geoid model has increased substantially during the last few decades especially after advent of Global Positioning System (GPS). Thus, the need for transformation of the ellipsoidal heights obtained from GNSS technique to the orthometric heights has forced geodesists to determine the high precision geoid heights. Today, it is possible to obtain a gravimetric geoid better than $10 \mathrm{~cm}$ accuracy by using global models and gravity data with 1-2 mGal accuracy. And you can only check such geoid only with GPS/levelling heights which provide better accuracies.

In this project it has been aimed to obtain a geoid model better than $5 \mathrm{~cm}$ in local areas in Turkey. In order to reach this aim, a pilot project has been launched in Central Anatolia. $140 \mathrm{~km}$-long line has been chosen and along this line relative gravity, GPS and levelling measurements have been performed. It is anticipated to complete the gravimetric geoid and quasi-geoid (geometric) computations using GRAVSOFT and DFHRS softwares, respectively. And, according to the results to be obtained from this project, the project area will be enlarged and thus additional densification data will be collected by carrying out relative gravity, levelling and GPS measurements for the determination of a high accuracy gravimetric geoid. And as a last step, a geoid determination project will be initiated for whole Turkey to reach a geoid model better than $5 \mathrm{~cm}$.

\section{ACKNOWLEDGEMENT}

This work is supported by the Scientific Research Project Fund of SELÇUK ÜNIVERSİTESİ under the project number 17401151. 


\section{REFERENCES}

DFHRS, 2018, Digital Finite Element Height Reference Surface, The User Guide, Hochschule Karlsruhe Technik und Wirtschaft (HSKA).

Jekeli, C., 2000, Heights, the Geopotential and Vertical Datums, Dept.of Civil and Environmental Engineering and Geodetic Science, OSU, 2000.

Sanso, F., R., Barzaghi, G., Sona, C., Vajani, 2008, GRAVSOFT lecture Notes, International Geoid Service, DIIAR-Politecnico di Milano.

Vanicek, P., 2009, Why Do We Need a proper Geoid? FIG Working Week Eilat May 6, 2009. 